doi:10.12662/2359-618xregea.v9i3.p240-253.2020

ARTIGOS

\title{
THE CHALLENGES FOR DEVELOPING A PUBLIC AGENDA UNDER INDUSTRY 4.0
}

\author{
OS DESAFIOS PARA A CONSTRUÇÃO DE UMA \\ AGENDA PÚBLICA A PARTIR DA INDÚSTRIA 4.0
}

\begin{abstract}
The term Industry 4.0 was used in 2011 in Germany and is being called the fourth industrial revolution. It encompasses the implementation of high technology capable of making the "Intelligent Factory", in order to increase productivity and go beyond that, integrate production, machines, and users with the use of communication technologies. It is not only about the increase of new technologies in production but will reach dimensions in labor relations, in social and institutional spaces, and regulation. Therefore, the objective of this paper is to identify the main guidelines that should integrate the public agenda of governments with the advent of industry 4.0. For this purpose, bibliographic research was used. The main results of this research were the following: regulation of new technologies, training, and adaptation of the labor market, integration of the public management systems through IoT, policies to stimulate the implementation of the main technologies and innovations in Industry 4.0, not only in economic activities but also improve the distribution systems of public services and sustainability.
\end{abstract}

Josélia Elvira Teixeira joseliat@hotmail.com Pós-Doutoranda em Economia. Professora Adjunta do Departamento de Ciências Econômicas da Universidade Estadual do Centro-Oeste. Guarapuava - PR - BR.

Silvio Roberto Stefani professor-silvio@hotmail.com Pós-Doutorando em Gestão pela FEP - Universidade do Porto. Professor Associado da Universidade Estadual do Centro-Oeste UNICENTRO. Guarapuava - PR - BR.
Keywords: Industry 4.0. Public Policy. Public Agenda. Technological Change.

\section{RESUMO}

O termo Indústria 4.0 foi utilizado em 2011, na Alemanha, e está sendo denominada como a quarta revolução industrial. Compreende a implementação de alta tecnologia capaz de tornar a "Fábrica Inteligente", com a finalidade de aumentar a produtividade e ir além disso: integrar a produção, as máquinas e os usuários com a utilização de tecnologias da comunicação. Não se trata somente do incremento de novas tecnologias na produção, mas atingirá dimensões nas relações do trabalho, nos espaços sociais e institucionais e de regulação. Portanto, o objetivo deste trabalho é identificar as principais pautas que deverão integrar a agenda pública dos 
governos com o advento da Indústria 4.0. Para tanto, foi utilizada a pesquisa bibliográfica. Como principais resultados, observou-se que as principais pautas de uma agenda pública relacionadas à intensificação da Indústria 4.0 serão regulação das novas tecnologias, capacitação e adequação do mercado do trabalho, integração dos sistemas de gestão pública por meio das IoT, políticas de estímulo para a implantação das principais tecnologias e inovações na Indústria 4.0, não só nas atividades econômicas, mas no aperfeiçoamento dos sistemas de distribuição de serviços públicos e sustentabilidade.

Palavras-chave: Indústria 4.0. Política Pública. Agenda Pública. Mudança Tecnológica.

\section{INTRODUCTION}

The integration of high technology in robotics with artificial intelligence and the internet of things is revolutionizing shop floor operations. The pressure that is imposed by global competitiveness has already shaped an increasing production process of goods and services, and it has become imperative the use and development of increasing innovations in productivity and processes. However, it does not concern only about the increase of technology; experts point out a transformative process of production that will lead the economy to the encounter of a Fourth Industrial Revolution (LI, 2018).

The German government unveiled Industry 4.0 to the Fourth Industrial Revolution, in 2011 (NAZAROV; KLARIN, 2020). This Fourth Industrial Revolution is marked by many technological trends that will allow the improvement and efficiency in productivity, services, and "the lives of people, in the health and transportation sector, as well as in other economic sectors." (BRITO, 2017, p. 94). Emerging technologies such as Artificial Intelligence (A.I.), robotics, the Internet of Things (IoT), 3D printing, nanotechnology, biotechnology, material sciences, storage, augmented reality, are only the tip of the iceberg that is yet to come because of the confluence of using all of them to reduce costs and improve services and products. This revolution has not been comprehended, and its potential and the ability to transform sociotechnical systems (SCHWAB, 2016).

The use of all of those technologies combined may bring many benefits for their users, including the government and private companies. However, this high connectivity of users, companies, and government bring challenges that were not predicted by any regulatory framework, as for instance, referring to data privacy and security. In the case of the advancement of the IoT and Big Data, they offer solutions to many different problems that need public policy such as pollution, traffic jams, productivity, public security, and others (MAGRANI, 2018). A few decades ago, it was unimaginable to think of the speed and range that this connectivity would encompass.

When searching the WoS with the keywords ("industry 4.0" OR "Fourth Industrial Revolution", 1.675 records were found (December 2020). These publications are from the period 1999 to 2021. The growing interest in the subject has appeared in different areas of knowledge. In the area of management, business and economics, 301 records were found from the period 2012 to 2020 . However, when the search is limited to the keywords ("industry 4.0" OR "Fourth Industrial Revolution" AND "public policy") only 58 records were shown. There is a gap in the review literature about policies publics to Industry 4.0.

Therefore, the objective of this paper is to identify the main guidelines that must integrate government public agenda with the emergence of Industry 4.0. This paper does not attempt to be prescriptive, rather, it attempts to understand via analysis of the identification of the main changes that are within Industry 4.0 the demands that must integrate the scope in the making of a public agenda. The main turning points that congregated technology in the Industry 4.0 brings to society (and will be used as guidelines in the making of a public agenda, which may result in specific public policies) 
have been compiled by bibliographic research.

\section{LITERATURE REVIEW}

\subsection{THE INDUSTRY 4.0 AND THE FOURTH INDUSTRIAL REVOLUTION}

The concept of the Industry 4.0 emerged in Hanover, in 2011, to spread the use of computerization of production processes, as well as the increase of connectivity and new ways of interactivity between men and machinery, $3 \mathrm{D}$ printing, and augmented reality, in addition to intensifying the implementation of robotics (SUÁREZ et al., 2019). "The German government that intends to introduce a paradigm shift toward a digital future in industrial production." (MÜLLER, 2019, p. 1128).

Some analysts have identified Industry 4.0 as the Fourth Industrial Revolution (MORRAR; ARMAN; MOUSA, 2017; LI, 2018; KUMAR; KUMAR, 2019; NAZAROV; KLARIN, 2020; ZHANG; CHEN, 2020). Sung (2018) argues that we can use the two terms, Fourth Industrial Revolution and Industry 4.0, interchangeably. However, Kupfer (2016) disagrees with that statement; the concepts of "advanced manufacture" and "Industry 4.0" together represent a spectrum of a future that is not far away from now, which will transform shop floor into smart factories. The management of emerging technologies such as information technology and communication with the purpose of digitalization the processes will allow reaching a better efficiency, quality, and possibility of customization. The German Ministry of Economics and Energy (2019) acknowledges that the process that is happening is a fourth industrial revolution.

Kupfer (2016) understands that Industry 4.0 or Advanced Manufacturing are only a set of techniques when combined allow the coordination of the use of information, automation, computing, software, remote sensing, and network connection.

In the United States, the government had created in 2011 the Advanced Manufacturing Partnership (AMP) (TESSARINI JUNIOR; SALTORATO, 2018). The term Advanced Manufacturing has stood out after being chosen as one of the main guidelines the strategic plan elaborated by the American government $\mathrm{A} \mathrm{Na}$ tional Strategic Plan for Advanced Manufacturing (EXECUTIVE OFFICE OF THE PRESIDENT AND NATIONALAND NATIONAL SCIENCE AND TECHNOLOGY COUNCIL, 2012). Meanwhile, the term Industry 4.0 has been introduced in 2012 by the German government for the launching of a national technology converting program (The Vision: Industrie 4.0, Federal Ministry for Economic Affairs and Energy, 2012). This initiative gathered the Ministry of Economics and Energy with leading companies, universities, and research institutes from Germany (KUPFER, 2016).

The governments have continued with actions to stimulate investments in emerging technologies; the successor of Advanced Manufacturing was the Accelerating US Advanced Manufacturing (AMP 2.0) in 2014 (NATIONAL SCIENCE AND TECHNOLOGICAL COUNCIL- USA (2018). China has developed the program "Made in China 2025" in 2015 that established the goals for converting emerging technologies between 2020 and 2025 (LI, 2018). South Korea presented Korea Advanced Manufacturing System (KAMS) with objectives such as creating new processes and technologies for the managing and integration of productivity systems (SUNG, 2018; TESSARINI JUNIOR; SALTORATO, 2018). India has been the fourth country (following the U.S, China and Japan) to establish a center for the Fourth Industrial Revolution by the World Economic Forum (OHM; PARTHASARATHI; STÅHLBERG, 2018).

Kupfer (2016) defended that the emerging technologies used in Industry 4.0 are meant to available increasing innovations that depend on intensifying their use. The closest and most accurate analogy to Industry 4.0 would be the post-Fordist or Toyotist model of production: lean production and total quality. However, Schwab 
(2016) strongly believes that the contemporary phenomenon that is happening is a Fourth Industrial Revolution, and not a consequence of the Third Industrial Revolution. Tunnicliffe (2018), Ohm, Parthasarathi and Stahlberg (2018), Xu, Xu and Li (2018), Skilton and Hovsepian (2018), Sukhodolov (2019), Endow (2019), and Suárez et al. (2019) have also identified Industry 4.0 as the Fourth Industrial Revolution.

Industry 4.0 influences all economic and social spheres. People will have to adapt to the changes imposed by the new economic conditions, and they will have to develop new abilities to adapt to these new possibilities brought by Industry 4.0 (SUKHODOLOV, 2019). Industry 4.0 requires a combination of emerging new technologies, including CPS (Cyber-physical Sistems), big data analytics, Internet of things (IoT), additive manufacturing, virtual reality, cloud computing, robotic systems, and artificial intelligence (ZHANG; CHEN, 2020).

According to Rüßmann et al. (2015) the nine pillars of technological advancement of the Industry 4.0 are Big Data, autonomous robots, Internet of things (IoT), simulation, augmented reality, horizontal and vertical systems integration, the cloud, additive manufacturing, and cybersecurity. "During the Fourth Industrial Revolution, the use of cyber-physical systems (CPS) has triggered a paradigm shift in industries, in particular the manufacturing sector." (XU; XU; LI, 2018, p. 2942). Cyber-physical systems can cooperate and communicate with each other and with humans in real-time, all enabled by the IoT and related services. The debate has been formulated by challenges about the best way to use advanced technological innovation to improve various aspects of human life (MORRAR; ARMAN; MOUSA, 2017).

\subsection{PUBLIC POLICY AND PUBLIC AGENDA CONCEPTS}

Schumpeter's prediction, in which he believed that science development and technology innovations would be more predictable and usual, ended up failing (NELSON, 2006).
The main world economies' paths throughout history ended up contradicting that statement, and the governments had a fundamental role in the construction and evolution of the National Systems of Innovation. In the previous session, it has been discussed that the big transformations that are happening, are not being comprehended in their totality. However, some governments have already taken the lead in better comprehending this process that was boosted by Industry 4.0 .

The governments have shown their roles as propagators of emerging technologies since Schumpeter's time. Academic research and governmental agencies' incentives coordinate investments for points considered strategic within capitalist economies (NELSON, 2006). However, public funding to research and development $(P \& D)$ is only one example of public policy that governments may implement to update to or foresee huge shifts caused by technology changes or in consequence of industrial revolutions.

"The policies may be considered as intentions or actions or most probably a mix of the two." (PAGE, 2006, p. 210). The State and its institutions may be comprehended as organizations that seek to meet goals, which are not always solutions to social demand, through public agents (elected ones or not). Sometimes these objectives are underpinned according to groups of interests that have the power to influence actions that structure and shape the process (DEUBEL, 2007).

According to Dye (2013), most of the public policies are derived from a combination of rational planning, development, and competition among groups of interests, the preferences given by the elites, public choice, the political process, and institutional influence. The author defines public policy as "what governments choose to do or not to do." (DYE, 2013 , p. 3). Even when a government does not elaborate a specific public policy to answer a certain demand, choosing not to do it is already considered a public policy (AGUM; RISCADO; MENEZES, 2015).

Public policy is a result of a series of 
grouped activities. The process of elaborating a public policy includes identifying a problem, being able to draw the attention of policymakers for that problem and include it in the agenda, formulating proposals, and legitimizing them by law. This process continues with its implementation and assessment of its execution after it (DYE, 2013).

The elaboration of agendas may allow elaborating a framework that offers the possible causes that determine the inclusion of certain guidelines over others that remained in obscurantism. Whereas other questions were enlightened in the public debate, getting attention from policymakers to make them susceptible to elaborating public policies or other public measures (PAGE, 2006). Hill (2005) argues that the nature of the public process arises from economics. The actors are understood as rational individuals that follow a strategy of satisfying their interests. Thus, the analysis of public policies is also limited to examining how decisions are made and how they are determined and influenced by the force of economic powers.

\section{METHODOLOGY}

It is a bibliographic research: Web of Science (WoS), Ebsco, Scribd, Scielo, and Google Scholar were used as repositories for gathering books, scientific articles from journals, and other specific materials related to the area of study. The main keywords for the search were "Industry 4.0", "Fourth Industrial Revolution" and "Public Policy" in years 2010 to 2020.

Dye (2013) considers that public policy is a result of a set of activities and the author identifies the phases of this elaboration process. The main phases are:

a) identify the problem through individual or group demand;

b) establish the agenda that makes public agents or policymakers to pay attention to a certain problem;

c) formulate politics that involve the presentation of proposals by groups of interests or policymakers;

d) legitimize the policy that should be assessed by legislators or executives;

e) implement policy without neglecting bureaucracy, expenses, public budget, regulation, and other public agencies activities;

f) evaluate the policy by public agencies that are involved by the effectiveness and necessity of continuing the policy or not.

The focus of the bibliographic research is to identify the problems or demands that may be generated from the implementation of the crucial cornerstones of Industry 4.0 as described by Rüßmann et al. (2015). The nine pillars of technological advancement of the Industry 4.0 marked are: Big Data, autonomous robots, Internet of things (IoT), simulation, augmented reality, horizontal and vertical systems integration, the cloud, additive manufacturing, and cybersecurity (Figure 1). According to the background theory about Industry 4.0 the nine pillars choose by Rüßmann et al. (2015) are the main trends to the technologies used in manufacturing.

Figure 1- Nine Technologies are transforming industrial production

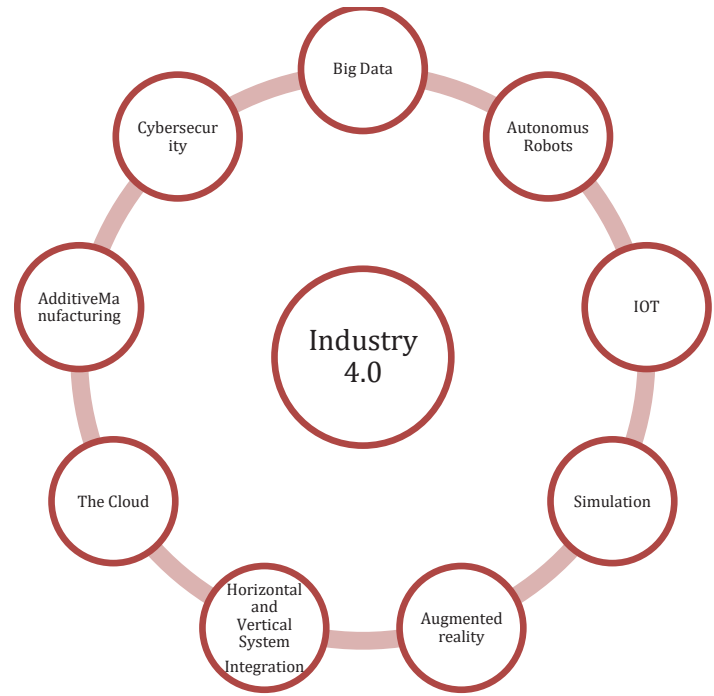

Source: (RÜßMANN et al., 2015, online).

The gathering of demands was elaborated by both the systematization of the readings that 
presented the problems and demands discussed and to each pillar technological advancement.

\subsection{THE INDUSTRY 4.0 AND THE NEW GUIDELINES FOR A PUBLIC AGENDA}

\subsection{THE MAIN TECHNOLOGIES THAT MAKE UP THE INDUSTRY 4.0}

The fourth industrial revolution is already acknowledged as a global tendency. Germany pioneerly recognized this process. Many of its leading competitors recognize this tendency from the use of IoT in the industrial setting and promote the use of them (GTAI, 2014). Industry 4.0 mixes production methods with the most advanced information technology and communication. Products can be customized in accordance with the consumer's likes, but with the price of mass products, thanks to smart and digitized systems and processes. Industry 4.0 determines the products' life cycle: from the concept to the development, manufacturing, use, and maintenance to recycling (FEDERAL MINISTRY ECONOMICS FOR AFFAIRS AND ENERGY, 2019). However, the fourth industrial revolution is not only about smart and connected systems and machinery. The externality of this trend is much broader and is seen simultaneously from gene sequencing to nanotechnology, from renewable energy to quantic computing (SKILTON; HOVSEPIAN, 2018). The development of the Internet of Things (IoT) and cyber-physical systems changed the supply chain models and smart operations (IVANOV; DOLGUI; SOKOLOV, 2019).

Rüßmann et al. (2015) point out to nine pillars that integrate the concept of Industry 4.0: Big Data, autonomous robots, Internet of things (IoT), simulation, augmented reality, horizontal and vertical integration systems, the cloud, additive manufacture, and cybersecurity. According to Skilton and Hovsepian (2018), the fourth industrial revolution is different from the previous ones because it is a fusion of tho- se technologies and their interactions through physical, digital, and biological domains. Understanding how these technologies are expanding and being used together and their main functions are understanding the core of Industry 4.0. Therefore, these main technologies that support industry 4.0 will be presented next.

The factory of the future will have a large amount of data involved in processes and these data will need to be saved, processed, and analyzed (ROLAND BERGER STRATEGY CONSULTANTS, 2014). "Big Data, a term used to describe mechanisms of organizing large amounts of structured, semistructured or not structured data that may be potentially explored to obtain information." (MAGRANI, 2018, p. $2)$. The analysis of the data will enable real-time decision making. Simultaneous evaluations will be made with the analysis of this set of data in the world of manufacturing employing many resources: it may be made by the equipment, customer systems, and management. All of this will contribute to the optimization of production quality, saving energy, and improving equipment services (RÜSSMANN et al., 2015). Currently, most of the companies do not know what to do with the large amounts of data and how useful they are at decision making (SUÁREZ et al., 2019).

"Robotics is viewed as one of core technologies that could fuel the industrial transformation envisaged by the concept of Industry 4.0, next to the Internet of things and the use of big data." (KLINCEWICZ, 2019, p. 57). The use of autonomous, flexible, and cooperative robots will be intensified, in manufacturing production. The intensification of its use will decrease robot prices. They will be able to interact among themselves and work with humans. They will be able to learn from them (RÜSSMANN et al., 2015). However, these robots will not only work side by side with humans in interconnected tasks; there will also be smart interfaces with man-machine sensors (SUÁREZ et al., 2019). Companies are already able to build robots with applications that use Artificial Intelligence (A.I.), that is to say, 
these robots are capable of learning and they can communicate with other systems, robots, and humans. These autonomous robots (RPA - Robotic Process Automation) combine different technologies such as autonomous systems, learning machines, robotic and artificial intelligence. These technologies shape these new patterns of robots (RPA), offer new solutions, and become a framework to RPA (KAYA; TURKYILMAZ; BIROL, 2019).

The Internet of Things (IoT) approach understands that computers, sensors, and objects will have interaction and data processing in the hyperconnectivity field. "IoT involves a set of objects that are interconnected with the internet that creates an ecosystem of omnipresent computing in order to facilitate and bring solutions to everyday challenges." (MAGRANI, 2018, p. 1). The "internet of things" is the most meaningful trend in Industry 4.0 (BASL, 2018). The increase of connectivity to the internet decreased connection costs; on the other hand, many devices that use WiFi and other sensors that contribute to the generation of the Internet of Things. Beyond the Internet of Things, the internet is expanding to the Internet of People (IoP) in which personal data and network are established from products and services; the focus is on the individual's privacy (SKILTON; HOVSEPIAN, 2018). Additional$\mathrm{ly}$, the internet of services and data are developed, and therefore the concept extends to the internet of everything (ARKTIS, 2015).

Therefore, the simulation will be performed in the factory to analyze available data in real-time, this way the physical world can be captured into a virtual world in 3D (RÜSSMANN et al., 2015). This procedure may include machines, products, and humans with a focus on reducing machinery setting time and increasing productivity (SUÁREZ et al., 2019). The intelligence of automation of unit systems, people, and organizations in a digital format (LAHTI; SAURUS; HELLGREN, 2018).

Augmented reality consists of mixing the physical content to elaborate a mixed real- ity in real-time (SUÁREZ et al., 2019). These systems are still in the initial phase of development, but in the future, they will contribute to offering workers information in real-time to enhance their procedures in the execution of work and decision making. This system supports a variety of services, such as selecting parts in a deposit and sending instructions of repair through mobile devices (RÜSSMANN et al., 2015). Most companies, suppliers, and customers are rarely integrated by an information technology system. Industry 4.0 promotes horizontal and vertical integration systems, in which a universal connection is established that is able to involve the value chain, making companies, departments, functions, capacities, and clients more cohesive (RÜSSMANN et al., 2015). Companies started to use data storage in clouds and some analytical applications. However, the necessity of intensifying the sharing of data on websites and companies is remarkable. Cloud technologies are being enhanced to the point of monitoring and controlling processes that may be based on the cloud (RÜSSMANN et al., 2015).

Companies already use additive manufacturing with $3 \mathrm{D}$ printing and they usually use a prototype to produce an individual component (RÜSSMANN et al., 2015). 3D printing builds an object in a tridimensional way using a digital model (SCHWAB, 2016). Additive manufacture is a process of automated fabrication underpinned in making tridimensional physical objects from 3D-CAD data without using tools that depend on pieces. It has been originally named 3D printing (GEBHARDT, 2012).

Cybersecurity will be vital for Industry 4.0 , once companies will need to intensify the use of connectivity and production systems will need data protection (RÜßMANN et al., 2015; SUÁREZ et al., 2019). In France, $63 \%$ of installation managers consider cybersecurity crucial for its competitiveness (SKILTON; HOVSEPIAN, 2018). Cyber-physical systems connect virtual space to physical reality, integrating computing, communication, and storage skills. "Communication must happen in real-time reli- 
ably and safely, with a stable and efficient operation." (CHENG et al. 2016 apud SILVA, 2017, p. 22). In addition, the use of nanomaterials and nanosensors makes it possible for automated vehicles to be a megatrend for the development of the industry (SCHWAB, 2016).

The revenues of the manufacturing sector will increasingly depend on the rise of new technologies (LORENZ et al., 2015). The implementation of Industry 4.0 predicts a better efficiency in the production and decrease of costs (RODRIGUES; JESUS; SCHÜTZER, 2016). Soon, workers, machines, feedstock, and robots will establish real-time communication; digitalization will transform factories into smart factories.

\subsection{NEW ONGOING GUIDELINES TO STRUCTURE A PUBLIC AGENDA IN THE LIGHT OF THE INDUSTRY 4.0}

Nationalist protection policies of invention and innovation already integrated the set of policies in the old mercantilism in the initial period of the first Industrial Revolution in Great Britain. Protection measures depended more on an entrepreneurial performance that kept monopolistic exploitation of radical innovations that became crucial to the presented concentration (FREEMAN; SOETE, 2008). The diffusion of Industry 4.0 will demand overcoming actions to deal with regulatory bottlenecks and technological infrastructure (KUPFER, 2016), especially in countries in which technological and industrial development are late. There are just a few competitive sectors in all of these technologies on a global scale (BRITO, 2017), referring to Brazil's scenario. Upon reflection about the challenges that countries face to elaborate a positive agenda to increase their competitiveness, a theoretical framework, which concentrated on the main concepts that characterized Industry 4.0, has been found using bibliographic research. It has been observed that the main definitions that gathered a set of high technology that confers to Economics the title of being under the process of adoption of the Industry 4.0. From then on, some problems and demands, which emerged from the implementation of those technologies, and some authors, who already discuss those issues in recent literature, have been deduced. These problems or demands for some countries, e.g. Germany (GTAI, 2014); The United States (most recently launching the Strategy for American Leadership in Advanced Manufacturing Plan in 2018) included in their public agenda, and they have already become public or private policies, whereas in other countries those demands are still in a phase of the debate (NATIONAL SCIENCE AND TECHNOLOGICAL COUNCI- USA, 2018).

We present below some of these demands and problems from the main technologies that support Industry 4.0 according to Rüßmann et al. (2015) and The Boston Consulting Group that in 2018 performed a study in 26 countries to identify the main digital champions guided by those technologies.

For each technology, some demands or problems that will be included in the possible public agenda guidelines will be discussed or remarked on by some researchers that are presented next:

-Big Data: It will demand the improvement of the means of data managing generated by companies (LORENZ etal., 2015; SUÁREZ et al., 2019; RÜSSMANN et al., 2015; BASL, 2018; GEISSBAUER et al., 2018; SCHWAB, 2016). There will be a reduction of people in the quality control and an increase of scientists in the data field as a consequence of the implementation of Big Data (LORENZ et al., 2015; TESSARINI JUNIOR; SALTORATO, 2018; SCHWAB, 2016). Comparative data in many different areas and sectors and solution generators will be used (GTAI, 2014; SCHWAB, 2016; MAGRANI, 2018; SKILTON; HOVSEPIAN, 2018; FEDERAL MINISTRY ECONOMICS FOR AFFAIRS AND ENERGY, 2019; NARULA et al., 2020 ).

-Autonomous Robots: Increase of productivity and competitiveness of companies 
(GTAI, 2014; ROLAND BERGER STRATEGY CONSULTANTS, 2014; ARKTIS, 2015; LORENZ et al., 2015; ENDOW, 2019; TESSARINI JUNIOR; SALTORATO, 2018; RODRIGUES; JESUS; SCHÜTZER, 2016; SCHWAB, 2016; KUMAR; KUMAR, 2019; FEDERAL MINISTRY ECONOMICS FOR AFFAIRS AND ENERGY, 2019; NARULA et al., 2020). Replacement of human work over machines that can learn (GTAI, 2014; ROLAND BERGER STRATEGY CONSULTANTS, 2014; LORENZ et al., 2015; TESSARINI JUNIOR; SALTORATO, 2018; LAHTI, SAURUS; HELLGREN, 2018, KLINCEWICZ, 2019). Autonomous industrial robots that cooperate with human workers (NARULA et al., 2020). Alteration of working relationships between company and men-machines-robots (GTAI, 2014; ROLAND BERGER STRATEGY CONSULTANTS, 2014; RÜSSMANN et al., 2015; LORENZ et al., 2015; ENDOW, 2019; MOHELSKA; SOKOLOVA, 2018; SKILTON; HOVSEPIAN, 2018). Workers' capacitation must be reconsidered and the educational system must prepare a worker that is able to interact with robots (ROLAND BERGER STRATEGY CONSULTANTS, 2014; ARKTIS, 2015; LORENZ et al., 2015; RÜSSMANN et al., 2015; ENDOW, 2019; MOHELSKA; SOKOLOVA, 2018; BRITO, 2017; SCHWAB, 2016; SKILTON; HOVSEPIAN, 2018; GLEASON, 2018).

-Internet of Things (IoT): It will have to face challenges such as health care, urban mobility, safety and urbanism (GTAI, 2014; MAGRANI, 2018; BASL, 2018; SANTOS, 2017; GEISSBAUER et al., 2018; WOLLSCHLAEGER; SAUTER; JASPERNEIT, 2017; SCHWAB, 2016; SKILTON; HOVSEPIAN, 2018). Countries will need to enlarge the network's expansion capacity (GTAI, 2014; SCHWAB， 2016; WOLLSCHLAEGER SAUTER; JASPERNEIT, 2017; MAGRANI, 2018; GEISS BAUER et al., 2018; XU; XU; LI, 2018). One of the main current demands is the regulation of the internet of all that is already being executed and discussed in some countries (SCHWAB, 2016; WOLLSCHLAEGER; SAUTER; JASPERNEIT, 2017; TESSARINI JUNIOR; SALTORATO, 2018; SKILTON; HOVSEPIAN, 2018; ZHANG; CHEN, 2020).

-Simulation: Testing in the virtual world diminishes costs and increases the competitive advantages of the companies that own the system. Rüßmann et al. (2015), Santos et al. (2018) and Schwab (2016) discuss the changes of the insertion of $3 \mathrm{D}$ simulation in the production sector and the competitive advantages for the companies that use these techniques. Therefore, process speed and the ability to predict methods and processes of the production line at an earlier stage using 3D simulation will increase (JOOS, 2015; RÜSSMANN et al., 2015; SCHWAB, 2016; SKILTON; HOVSEPIAN, 2018).

-Augmented Reality: The use of this technology will create the necessity of companies to enlarge the use of the IoT, the capacity of R\&D and digital assistance systems (JOOS, 2015; LORENZ et al., 2015, TESSARINI JUNIOR; SALTORATO, 2018; SANTOS, 2017). There will be a generation of new business models and new services in the market (GTAI, 2014; LORENZ et al., 2015; WOLLSCHLAEGER; SAUTER; JASPERNEIT, 2017; SKILTON; HOVSEPIAN, 2018).

-Horizontal and Vertical Integration System: The total integration of companies, from their internal structure to their suppliers and consumers, has not been achieved yet (LORENZ et al., 2015; SANTOS, 2017; WOLLSCHLAEGER; SAUTER; JASPERNEIT, 2017; SKILTON; HOVSEPIAN, 2018).

-The Cloud: The demand for research and development of innovative storage methods will increase. Cloud computing economics will open Industry 4.0 to almost all organizations (ROLAND BERGER STRATEGY CONSULTANTS，2014; ENDOW，2019; SKILTON; HOVSEPIAN, 2018).

-Additive Manufacturing: There will be a creation of added value for the country and customization of mass products (GTAI, 2014; ROLAND BERGER STRATEGY CON- 
SULTANTS, 2014; SCHWAB, 2016; SANTOS et al., 2018; SKILTON; HOVSEPIAN, 2018). The high advantages of producing in cheap labor countries will decrease with Industry 4.0 (SANTOS et al., 2018; SCHWAB, 2016). It reduces the cycle of product development until the launching in the market (GTAI, 2014; SANTOS et al., 2018; SCHWAB, 2016; SKILTON; HOVSEPIAN, 2018; HALEEM; JAVAID, 2019).

-Cybersecurity: It deals with data protection and companies' industrial secrets (RÜSSMANN et al., 2015; SANTOS, 2017; SCHWAB, 2016). Data privacy will demand new systems and regulation (RÜSSMANN et al., 2015; SCHWAB, 2016; FERÁNDEZ-CARAMÉS; FRAGA-LAMAS, 2019).

On the contrary of what could have been thought, work development depends on the adoption of technologies Manufacturing sectors' revenues will increasingly depend on these technologies (ROLAND BERGER STRATEGY CONSULTANTS, 2014).

These technologies may offer solutions to the demands, not only in the private sector but especially for the competitiveness of industries and countries (ROLAND BERGER STRATEGY CONSULTANTS, 2014; GEISSBAUER et al., 2018). These technologies can also offer solutions for health care, urban mobility, collective security, recycling, among other applications in different areas that are related mainly to the interests of policymakers' actions (SCHWAB, 2016). Humanity's greatest concerns such as issues related to climatic changes, energy transformation, or large metropolis managing might receive many contributions from Industry 4.0's megatrends (GTAI, 2014).

\section{FINAL CONSIDERATIONS}

Industry 4.0 aggregates a set of technologies that connect manufacturing to suppliers and consumers, and it goes further, proposing a connection of the machines, men, robots, raw materials in real-time anywhere in the world. The main used technologies remain in develo- pment and allow constant improvement of the processes of product manufacturing and services. Big Data, augmented reality, the internet of all, 3D simulation, horizontal and vertical integration system, the cloud, additive manufacturing, and cybernetic security. Additionally to these technologies, their interaction through physical-digital, and biological domains, are characteristic of a Fourth Industrial Revolution.

Countries such as Germany have been the pioneers in adopting the term Industry 4.0, and the United States that have used the term "Advanced Manufacturing" are in a technological race to overcome infrastructure bottlenecks and technological limits. Since 2012, these countries have been showing a consistent agenda that converted into a strategic plan of public policies to stimulate the development of the main cornerstones that involve Industry 4.0. Whereas other countries still have incipient policies to answer to the demands that will emerge from this theme.

The main demands that may be suggested for inclusion into an observed public agen$\mathrm{da}$, through perusal are related to the development of the main technologies of Industry 4.0. The labor market will be affected by interaction among men, machines, and autonomous robots that will have the ability to learn. Governments will have to reconsider the educational and capacitation system for the labor market. Besides, the technologies that allow connection need public and private investments. Other problems related to connection are related to the regulation of the IoT and the matters regarding data security and companies' and individuals' information privacy.

All of these technologies together may contribute to the demands of countries' socioeconomic development and to elaborate on positive guidelines for countries' government's agendas. The construction of the agenda for inclusion in the public agenda is primarily related to competitiveness between countries. Increasing the competitiveness of companies can generate more jobs and income. However, the use of key technologies associated with industry 
4.0 requires new challenges. The regulation of these new technologies should also be among the main agendas on the government and private agenda. As a research suggestion are studies on the implementation, execution, and evaluation of public policies to support Industry 4.0.

\section{REFERENCES}

ABRAMOVAY, Ricardo. O poder é partilhado na revolução do século XXI. Valor Econômico, 24 jan. 2012. Available at: http://www.valor.com.br/impresso/cultura/o-poder-e-partilhado-na-revolucao-do-seculo-xxi. Accessed: 11 June 2019.

AGUM, Ricardo; RISCADO, Priscila; MENEZES, Monique. Políticas Públicas: conceitos e análise em revisão. Revista Agenda Política, v. 3, n. 2, p. 12-42, jul./dez. 2015.

ARKTIS. Indústria 4.0, a quarta Revolução Industrial. 2015. Available at: https://www. arktis.com.br/a-quarta-revolucao-da-industria/. Accessed: 4 June 2019.

BASL, Josef. Companies on the Way to Industry 4.0 and their Readiness. Journal of Systems Integration, v. 9, n. 3, p. 3-6, 2018.

BRITO, Alexandra Antonia Freitas de Brito. A Quarta Revolução Industrial e as perspectivas para o Brasil. Revista Científica Multidisciplinar Núcleo do Conhecimento, v. 2, p. 9196, Oct. 2017. Disponível em: https://www. nucleodoconhecimento.com.br/administracao/ quarta-revolucao-industrial. Accesso em: 17 June 2019.

DEUBEL, André Noel. Políticas Públicas: formulación, implementación y evaluación. Bogotá-DC: Aurora, 2007.

DYE, Thomas R. Understanding Public Policy. 14. ed. USA: Pearson Education, 2013.

ENDOW, Amberjit. The Fourth Industrial Rev- olution And Long-Term Value Creation. Corporate Board, v. 40, n. 236, p. 17-21, 2019. Available at: https://www2.deloitte.com/content/dam/Deloitte/de/Documents/human-capital/Deloitte_Review_26_Fourth_Industrial_ Revolution.pdf. Accessed: 17 June 2019.

EXECUTIVE OFFICE OF THE PRESIDENT AND NATIONAL AND NATIONAL SCIENCE AND TECHNOLOGY COUNCIL. A National Strategic Plan for Advanced Manufacturing. 2012. Available at: https:// www.energy.gov/sites/prod/files/2013/11/f4/ nstc_feb2012.pdf. Accessed: 17 June 2019.

FEDERAL MINISTRY ECONOMICS FOR AFFAIRS AND ENERGY. Industrie 4.0. Germany. 2019. Available at: https://www.bmwi. de/Redaktion/EN/Dossier/industrie-40.html. Accessed: 17 June 2019.

FERNÁNDEZ-CARAMÉS, Tiago M.; FRAGA-LAMAS, Paul. A Review on the Application of Blockchain to the Next Generation of Cybersecure Industry 4.0 Smart Factories. IEEE Access, v. 7, 16 abr. 2019. Available at: https://ieeexplore.ieee.org/stamp/stamp.jsp?t$\mathrm{p}=$ \&arnumber $=8678753$. Accessed: 6 June 2019. Doi: 10.1109/ACCESS.2019.2908780

FREEMAN, Cris; SOETE, Luc. A economia da inovação industrial. Campinas-SP: Editora da UNICAMP, 2008.

GEBHARDT, Andreas. Understanding Additive Manufacturing: Rapid Prototyping - Rapid Tooling - Rapid Manufacturing. Munich: Carl HanserVerlag GmbH \& Co. KG, 2012.

GEISSBAUER, Reinhard et al. Global Digital Operations Study - Digital Champions: How industry leaders build integrated operations ecosystems to deliver end-to-end customer solutions. BCG-The Boston Consulting Group. 2018. Available, at: https://www.strategyand. pwc.com/gx/en/insights/industry4-0/global-digital-operations-study-digital-champions. 
pdf. Accessed: 6 June 2019.

GLEASON, Nancy W. Higher education in the era of the fourth industrial revolution. Singapore: Pelgrave Macmillan, 2018.

GTAI-GERMANY TRADE \& INVESTMENTS. Industrie 4.0: Smart Manufacturing for the future, 2014. Available at: file:///C:/Users/Usuario/Downloads/GTAI\%20-\%20industrie4.0-smart-manufacturing-for-the-future-en. pdf. Accessed: 17 June 2019.

HALEEM, Abid; JAVAID, Mohd. Additive Manufacturing Applications in Industry 4.0: A Review. Journal of Industrial Integration and Management-Innovation and Entrepreneurship, v. 4, n. 4, 2019. DOI:10.1142/ s2424862219300011

HILL, Michael. The public policy process. 4 . ed. UK: Pearson Education, 2005.

IVANOV, Dmitry; DOLGUI, Alexandre; SOKOLOV, Boris. The impact of digital technology and Industry 4.0 on the ripple effect and supply chain risk analytics. International journal of production research, v. 57, n. 3, p. 829-846, 2019. DOI:10.1080/00207543.2018. 1488086

JOOS, Dorothea. Print on demand. Encounter. 22 may 2015. Available at: https://www. audi-mediacenter.com/en/publications/magazines/encounter-smart-factory-2015-156. Accessed: 20 Jun. 2019.

KAYA, Can. T.; TURKYILMAZ, Mete; BIROL, Burco. Impact of RPA Technologies on Accounting Systems. Journal of Accounting \& Finance, n. 82, p. 235-249, 2019.

KLINCEWICZ, Krzysztof. Robotics in the Context of Industry 4.0: Patenting Activities in Poland and Their Comparison with Global Developments. Problemy Zarzadzania-Management Issues, n. 17, v. 2, p. 53-95, 2019.
DOI:10.7172/1644-9584.82.3

KUMAR, Naveen; KUMAR, Jyoti.Efficiency 4.0 for Industry 4.0. Human Technology, v. 15 , n. 1, p. 55-78, 2019. ISSN: 1795-6889 Available at: https://humantechnology.jyu.fi/ archive/vol-15/issue-1/efficiency-4-0-for-industry-4.0/@@display-file/fullPaper/Kumar Kumar.pdf. Accessed: 20 Jul. 2020. https://doi. org/10.17011/ht/urn.201902201608

KUPFER, David. A indústria 4.0 no Brasil. Valor Econômico, 8 ago. 2016. Available at: https://valor.globo.com/opiniao/coluna/industria-4-0-brasil.ghtml_Accessed: 4 June 2019.

LAHTI, T.; SAURUS, L.; HELLGREN, N. Industry 4.0 in the oil and gas business. Hydrocarbon Processing, v. 97, n. 12, p. 75-78, 2018. Availableat: https://www.hydrocarbonprocessing.com/magazine/2018/december-2018/ industrial-internet-of-things-iiot/industry-40in-the-oil-and-gas-business. Accessed: $20 \mathrm{Jul}$. 2020 .

LI, Ling. China's manufacturing locus in 2025: With a comparison of "Made-in-China 2025" and "Industry 4.0". Technological Forecasting and Social Change, n. 135, p. 66-74, 2018. DOI:10.1016/j.techfore.2017.05.028

LORENZ, Markus et al. Man and machine in Industry 4.0: How will technology transform the industrial worforce through 2025? 2015. Available at: http://englishbulletin.adapt.it/ wp-content/uploads/2015/10/BCG_Man_and Machine_in_Industry_4_0_Sep_2015_tcm80197250.pdf.Accessed: 5 June 2019.

MAGRANI, Eduardo. A Internet das Coisas no Brasil: Estado da arte e reflexões críticas ao fenômeno. Artigo Estratégico 37, Rio de Janeiro, Instituto Igarapé, nov. 2018. Disponível em: https://igarape.org.br/wp-content/ uploads/2018/11/A-Internet-das-Coisas-no-Brasil-Estado-da-arte-e-reflexo $\% \mathrm{CC} \% 83$ es-cri $\% \mathrm{CC} \% 81$ ticas-ao-feno $\% \mathrm{CC} \% 82$ meno-E- 
duardo-Magrani.pdf. Acesso em: 5 June 2019.

MOHELSKA, H.; SOKOLOVA, M. Management Approaches for Industry 4.0 - the Organizational Culture Perspective. Technological \& Economic Development of Economy, v. 24 , n. 6 , p. $2225-2240,2018$. Available at: https://journals.vgtu.lt/index.php/TEDE/article/view/6397/5544. Accessed: 20 Jul. 2020. https://doi.org/10.3846/tede.2018.6397

MORRAR, Rabeh; ARMAN, Husam; MOUSA, Saeed. The Fourth Industrial Revolution (Industry 4.0): A Social Innovation Perspective. Technology Innovation Management Review, v. 7, n. 11, p. 12-20, 2017. DOI:10.22215/timreview/1117

MÜLLER, Julian Marius. Business model innovation in small- and medium-sized enterprises Strategies for industry 4.0 providers and users. Journal of Manufacturing Technology Management, v. 30, n. 8, p. 1127-1142, 2019. DOI:10.1108/jmtm-01-2018-0008

NAZAROV, Dashi, KLARIN, Anton. Taxonomy of Industry 4.0 research: Mapping scholarship and industry insights. Systems Research and Behavioral Science, v. 37, n. 4, p. 535-556, 2020. DOI:10.1002/sres.2700.

NARULA, Sanjiv et al. Industry 4.0 adoption key factors: an empirical study on manufacturing industry. Journal of Advances in Management Research, n. 29, 2020. DOI:10.1108/ jamr-03-2020-003

NATIONAL SCIENCE AND TECHNOLOGICAL COUNCI- USA. Strategy for American leadership in Advanced Manufacturing. A report by the Subcommitee on Technology of the National Science and Technological Council. 2018. Available at: https://www.whitehouse.gov/wp-content/uploads/2018/10/Advanced-Manufacturing-Strategic-Plan-2018. pdf. Accessed: 4 Dec. 2020.
NELSON, Richard R. As fontes do crescimento econômico. Campinas: UNICAMP, 2006.

OHM, Brita; PARTHASARATHI, Vibodh; STÅHLBERG, Per. Introduction: Critical Explorations of Media Modernity in India. Culture Unbound. Journal of Current Cultural Research, v. 10, n. 3, p. 322-331, 2018.

PAGE, Edward C. The origins of policy. In: MORAN, Michael; REIN, Martin; GOONDIN, Robert E. The Oxford Handbook of Public Policy. Oxford: Oxford University Press, 2006. p. 208-227.

PALACIOS, Julián Chaves. Desarrollo tecnológico en la primera Revolución Industrial. NORBA - Revista de Historia, v. 17, p. 93109, 2004. Available at: https://dialnet.unirioja. es/descarga/articulo/1158936.pdf___Accessed: 11 June 2019.

RODRIGUES, Leticia Francischini; JESUS, Rodrigo Aguiar de; SCHÜTZER, Klaus. Industrie 4.0 - Uma Revisão da Literatura. Revista de Ciência \& Tecnologia, v. 19, n. 38, p. 33-45, 2016. Available at: https://www.metodista.br/revistas/revistas-unimep/index.php/ cienciatecnologia/article/view/3176. Accessed: 17 June 2019. http://dx.doi.org/10.15600/22381252/rct.v19n38p33-45

ROLAND BERGER STRATEGY CONSULTANTS. Think Act: Industry 4.0 - The new industrial revolution How Europe will succeed. 2014. Available at: http://www.iberglobal.com/ files/Roland_Berger_Industry.pdf. Accessed: 17 June 2019.

RÜßMANN, Michael et al. Industry 4.0: The Future of Productivity and Growth in Manufacturing Industries. 2015. Available at: https:// www.bcg.com/publications/2015/engineered products_project_business_industry_4_future productivity_growth_manufacturing_industries. Accessed: 1 June 2019. 
SANTOS, B. P. et al. Indústria 4.0: desafios e oportunidades. Revista Produção e Desenvolvimento, v. 4, n. 1, p.111-124, 2018. Available at: https://revistas.cefet-rj.br/index.php/producaoedesenvolvimento/article/view/e316/193. Accessed: 20 Jul. 2020.

SCHWAB, Klaus. The Fourth Industrial Revolution. Geneva: World Economic Forum, 2016.

SCHUMPETER, Joseph A. Teoria do desenvolvimento econômico: uma investigação sobre lucros, capital, crédito, juro e ciclo econômico. São Paulo: Nova Cultural, 1997.

SKILTON, Mark; HOVSEPIAN, Felix. The 4th Industrial: responding to the impact of artificial intelligence on business. UK: PalgraveMacmillan, 2018.

SILVA, Danilo Goulart da. Indústria 4.0: Conceitos, tendências e desafios. 2017. 35 f. Trabalho de Conclusão de Curso em Tecnologia (Graduação em Automação Industrial) - Universidade Tecnológica Federal do Paraná, Ponta Grossa, 2017.

SUÁREZ, Jorge Carro et al. Industry 4.0 and Digital Manufacturing: a design method applying Reverse Engineering. Ingeniería, v. 24, n. 1, p. 50-71, 30 Jan. 2019. ISSN: 0121750X. Available at: https://revistas.udistrital. edu.co/index.php/reving/article/view/13821\#full-article. Accessed: 20 Jul. 2020. https://doi. org/10.14483/23448393.13821

SUKHODOLOV, Yakov A. The notion, essence, and peculiarities of Industry 4.0 as a sphere of industry. In: POPKOVA, Elena G.; RAGULINA, Yulia V.; BOGOVIZ, Aleksei V. Industry 4.0: Industrial Revolution of the 21st century: studies in systems, decision and control. Switzerland: Springer, 2019. v. 169.

SUNG, Tae Kyung. Industry 4.0: A Korea perspective. Technological Forecasting and Social
Change, n.132, p. 40-45, 2018. DOI:10.1016/j. techfore.2017.11.005

TESSARINI JUNIOR, Geraldo; SALTORATO, Patrícia. Impacts of the Industry 4.0 on work organization: a systematic review of the literature. Revista Produção Online, Florianópolis, SC, v. 18, n. 2, p. 743-769, 2018. ISSN: 1676-1901. Available at: https://producaoonline.org.br/rpo/article/view/2967. Accessed: 20 Jul. 2020.

TUNNICLIFFE, Helen. Industry X.0 - The Next Stage: What's coming, and why the process industries will have to be more nimble. TCE: The Chemical Engineer, n. 920, p. 3639, 2018. Available at: https://www.thechemicalengineer.com/features/industry-x0-the-nextstage/. Accessed: 15 June 2019.

WOLLSCHLAEGER, Martin; SAUTER, Thilo; JASPERNEIT, Jürgen E. The Future of Industrial Communication Automation Networks in the Era of the Internet of Things and Industry 4.0. IEEE Industrial Electronics Magazine, p.17-27, 21 Mar. 2017. Available at: https://ieeexplore.ieee.org/stamp/stamp.jsp?tp=\&arnumber $=7883994$. Accessed: 20 Jul. 2020.

XU, Li Da; XU, Eric L.; LI, Lingi.Industry 4.0: state of the art and future trends. International Journal of Production Research, v. 56, n. 8, p. 2941-2962, 2018. https://doi.org/10.1080/00 207543.2018.1444806

ZHANG, Caiming. M.; CHEN, Yong. A Review of Research Relevant to the Emerging Industry Trends: Industry 4.0, IoT, Blockchain, and Business Analytics. Journal of Industrial Integration and Management-Innovation and Entrepreneurship, v. 5, n.

1 p. $165-180$, 2020. DOI:10.1142/ s2424862219500192 